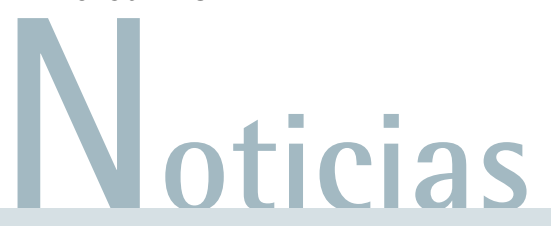

\section{LA FERIA DE SEVILLA. \\ TESTIMONIOS DE SU HISTORIA}

Salón del Apeadero del Real Alcázar de Sevilla. Marzo - Abril 1996

A raíz del éxito obtenido con la celebración de la exposición Sevilla. Imágenes de un siglo (visitada por más de 50.000 personas) -que tuvo lugar entre Marzo y Abril del pasado año-, era evidente que la experiencia había que repetirla y así lo comunicaron en su día las empresas que ejercieron el patronazgo de la muestra (Excelentísimo Ayuntamiento de Sevilla, Real Maestranza de Caballería de Sevilla, Prensa Española, Fundación Sevillana de Electricidad y Fundación El Monte).

La conmemoración del I 50 aniversario de la Feria de Abril era un motivo lo suficientemente atractivo para plasmar en una exposición el origen, evolución y transformación de la fiesta más universal de España.

El Excelentísimo Ayuntamiento de Sevilla junto a las entidades patrocinadoras mencionadas -a las que se unió la Fundación Cruzcampo- y a través de la Delegación de Fiestas Mayores encargaron a la dirección de de la Hemeroteca Municipal la puesta en marcha del proyecto, dado que es en este centro -concretamente en la Sección Fotográfica- donde se ubican los mayores depósitos de negativos fotográficos de toda Andalucía y uno de primeros de España. El grueso de los fondos lo constituye el legado de los tres archivos adquiridos por la Delegación de Cultura del Ayuntamiento entre 1985 y 1991, es decir los de Serrano y sus hijos, el de Cecilio Sánchez del Pando y el de Angel Gómez Beades "Gelán". Este importante legado se ha visto incrementado en los últimos años con otras coleccio-

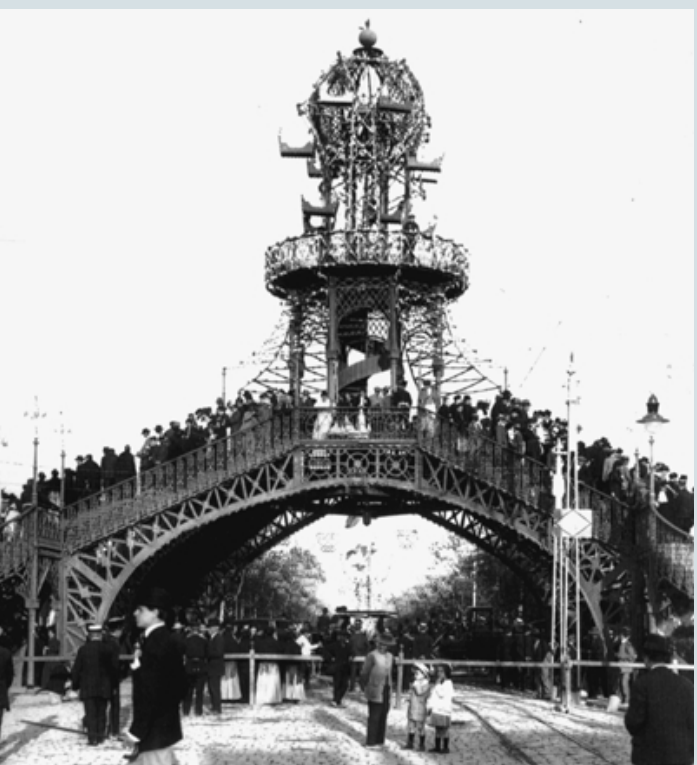

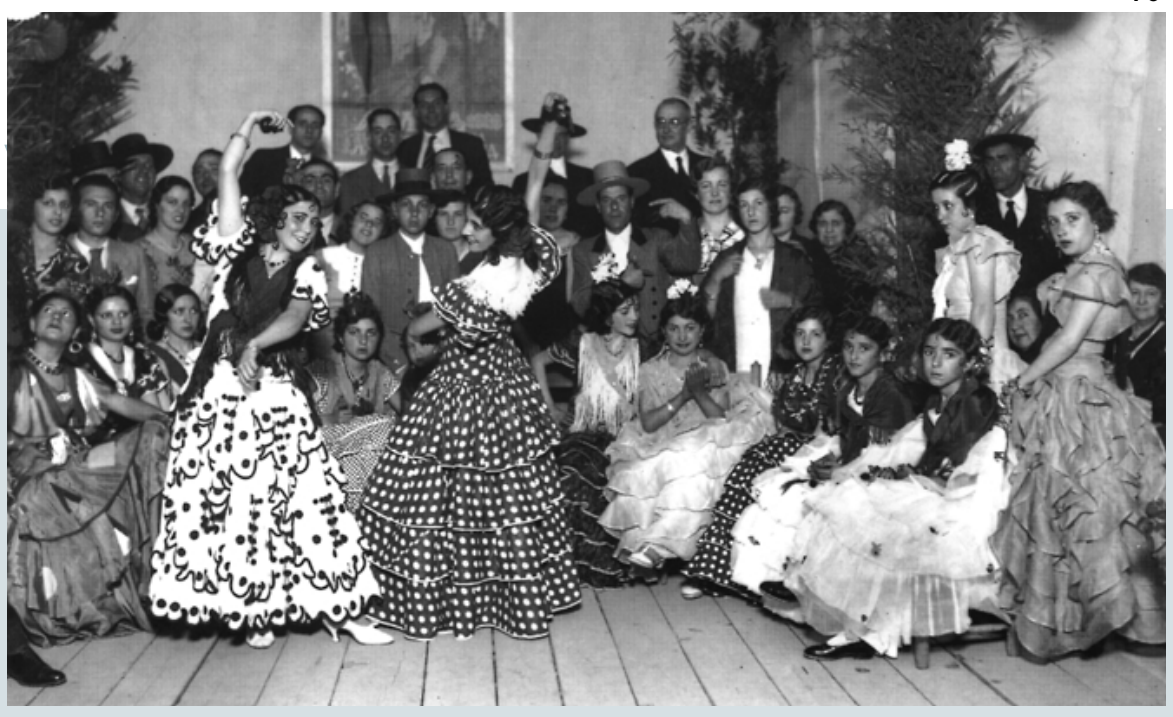

nes (aún sin catalogar) como son las de Serafín Sánchez Rengel, Francisco Macías y Rafael Cubiles. Se puede afirmar que el patrimonio fotográfico de este centro alcanza ya los 500.000 negativos en distintos formatos y soportes y con un período cronológico que abarca de primeros de siglo hasta la década de los 80 .

Dado el caracter conmemorativo de la muestra, se hacía necesaria la inclusión de otros atractivos para el visitante aún cuando la base principal la constituyese las 130 fotografías pertenecientes a los archivos arriba indicados. Así se han podido ver obras pictóricas, entre las que destaca el cuadro que en 1852 pintase Andrés Cortés La Feria de Sevilla, primer testimonio del festejo donde se plasma una panorámica del Prado de San Sebastián en pleno desarrollo de la fiesta, obra encargo del Conde de Ibarra, uno de los promotores -junto a Bonaplata- a cuyo servicio trabajaba el artista. Se recogen igualmente los originales de carteles anunciantes de las fiestas primaverales de la ciudad, con firmas tan importantes como García Ramos, Gustavo Bacarisas, Villegas o Juan Roldán. De gran interés es el plano que se ofrece del Prado de San Sebastián hacia 1860 en el que se reproduce la demarcación de cada parcela y donde debián ir ubicados cada uno de los distintos ganados, así como las zonas de recreo y expansión. Como curiosidad se han querido mostrar trajes de toreros -leyendas vivas de la historia de la Feria y de Sevilla-, como son los cedidos para la ocasión por Curro Romero y Manolo Vázquez.. De igual modo se reprodujo a tamaño real una caseta en la que se recogen los elementos arquitectónicos y decorativos propios de esta vivienda provisional.

Como se ha indicado la base de la exposición la constituyen 130 fotografías, reproducidas con una gran calidad, que reflejan no sólo el alto nivel de los reporteros gráficos citados, sino de los técnicos que hoy se han encargado de positivar y ampliar los originales.
Al iniciarse el proyecto se planteó qué formula sería la elegida para mostrar de un modo divulgativo a la vez que se cuidaría no caer en lo reiterativo al tratarse de un tema monográfico. Finalmente se optó por dividir el conjunto en diez bloques temáticos en los que se abordarían las distintas épocas de la fiesta y donde se apreciaría de un modo más elocuente la evolución de nuestra feria. Para la seleccción de las instantáneas se trabajó con unos 2000 negativos de los que se apartaron las 130 que contiene la exposición. El primer bloque se destina a Los orígenes en el que se recogen imágenes del Prado de San Sebastián -el lugar elegido en I 847 para la celebración de la primera feria de ganados-y donde se nos muestra una panorámica del recinto, así como detalles de los tratantes y la forma de vida de estos primitivos feriantes desde 1915 hasta la década de los 40, trasladado ya el mercado ganadero al campo de Los Remedios.

Un segundo panel está dedicado al Recinto ferial, con instantáneas recogen la evolución arquitectónica y decorativa tanto de las portadas y adornos de calles, como de las tiendas de lonas o casetas. En este bloque hay que hacer mención a la más conocida de las portadas, La Pasarela, -la desaparecida obra de la arquitectura del hierro- que a pesar de su corta vida -se inaguró 1899 y fue desmantelada en 1921-, ha perdurado en el recuerdo de todos los sevillanos e incluso en el nomenclátor de nuestra ciudad. Para un amante de la feria, la fiesta nos se inicia en las casetas, sino que existe todo un rito que constituye lo que se ha dado en llamar Los prolegómenos y más concretamente los preparativos de la mujer sevillana a la hora de vestir su "traje de gitana".

En los sucesivos paneles se describen gráficamente lo que se ha denomiado Paseo de coches y caballos, El cante y el baile, El ambiente, y La "calle del infierno" en los que se aprecian los momentos más brillantes de la fiesta, las personalidades que la han visitado -reyes y príncipes, presidentes de gobierno, políticos, 
aristócratas, artistas- y el protagonismo del baile y el cante por "sevillanas" en las casetas o en las calles del Real.

Las Curiosidades y sucesos reunen una serie de instantáneas que reflejan las distintas circunstancias singulares que han rodeado estos I 50 años, desde la celebración de unas curiosas corridas de toros en la propia caseta, pasando por el incendio de 1964 (el más grave de la historia), hasta el traslado al campo de Los Remedios en 1973.

Un apartado especial han merecido Las corridas de toros pues desde sus orígenes han estado muy ligadas al desarrollo de la Feria. De especial interés son la imágenes de los dos míticos toreros sevillanos Juan Belmonte y Rafael El Gallo, una singular estampa de Pepe Luis Vázquez, y una vuelta al ruedo de Curro Romero.

Con esta muestra no se ha pretendido sólo celebrar los 150 años de historia de la Feria, sino que además, se ha logrado hacer un análisis del origen -estrictamente mercado agropecuario- y su evolución hasta lo que hoy conocemos. Se nos permite igualmente adentrarnos en una reflexión del transfondo sociocultural del sevillano que acude a la

\section{MUSEUM PRACTICE, UNA NUEVA PUBLICACIÓN PERIÓDICA DE LA MUSEUM ASSOCIATION}

La Museum Association (MA), principal asociación de museos del Reino Unido, añade a su publicación mensual, Museum Journal, una nueva revista periódica denominada Museum Practice, donde se abordan aspectos prácticos y técnicos del trabajo en los museos. Su objetivo es perfeccionar el nivel profesional de la conservación, presentación e interpretación de las colecciones y conseguir una mejor utilización de los recursos disponibles y de las inversiones.

Museum Practice proporciona a los profesionales de museos y galerías información actualizada y orientaciones dentro de una amplia variedad de temas. Cada número incluye artículos y reseñas sobre proyectos de museos y galerías, publicaciones, eventos, investigaciones y nuevos productos dentro y fuera del Reino Unido.

\section{Información:}

\section{Museums Association}

42 Clerkenwell,

London ECIR OPA

Reino Unido

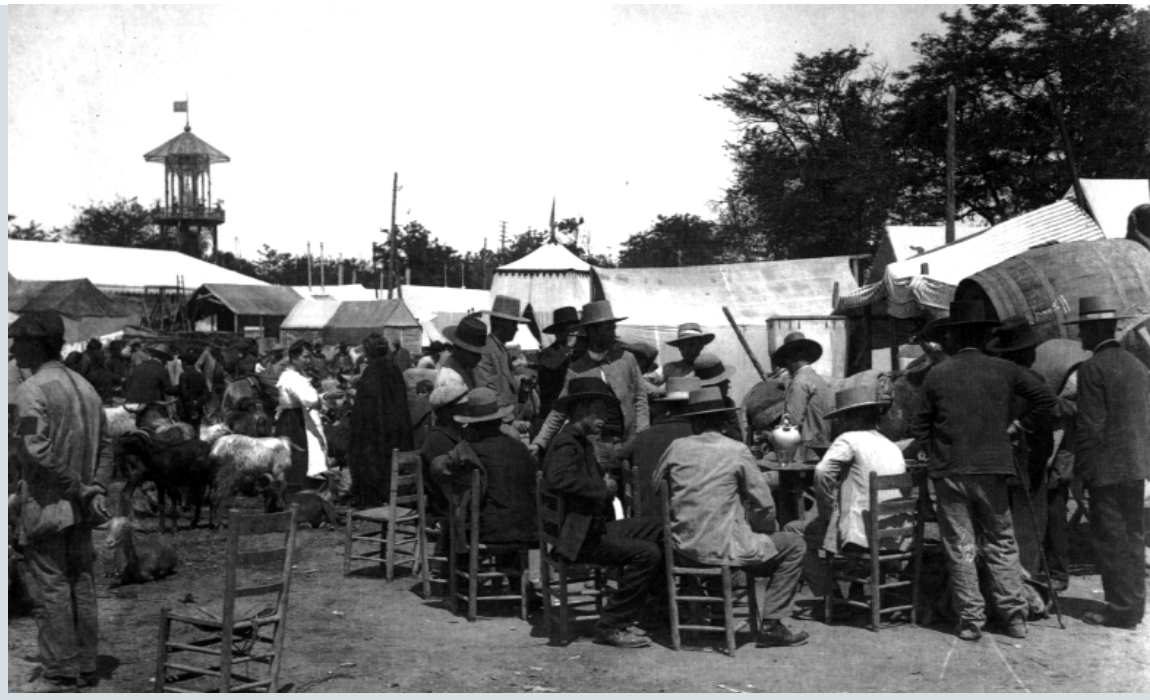

fiesta convirtiéndose ésta en un micromundo, reflejo de la sociedad actual.

Finalmente hay que hacer mención del librocatálogo editado para la ocasión. En él se recogen artículos alusivos a la historia de la Feria como 150 años de Feria de Abril de Nicolás Jesús Salas; La Feria de Sevilla en la pintura contemporánea de Enrique Valdivieso; La Feria en la literatura de Miguel Cruz Giráldez; Del amor que la Feria y el flamenco se otorgaron de José Luis Ortíz Nuevo; Siglo y medio de toros en Sevilla de Manuel Ramírez y Fernández de Córdoba; Las revistas de Feria (llusiones para un mensaje periodístico) de Alfonso Braojos; La Feria y el artículo periodístico de Julia Sánchez López; y Lógicas y míticas realidades en la Feria de la sociedad sevillana (aspectos sociológicos de la Feria de Abril) de Isabel Aler Gay.

Elena Hormigo León Hemeroteca Municipal de Sevilla

\section{CREACIÓN DE UN FORUM- UNESCO/UNIVERSIDAD $Y$ PATRIMONIO PARA FORMAR MEJOR A LOS FUTUROS ESPECIALISTAS EN PATRIMONIO}

El 19 de abril de 1996 se ha firmado en París, en la sede de la UNESCO, un acuerdo para la creación del Forum-UNESCO/Universidad y Patrimonio, primera red interuniversitaria en el ámbito de la salvaguarda del patrimonio cultural. El objetivo de esta red, que unirá a 538 universidades del mundo entero y cuyo centro se encontrará en Valencia (España), es formar de manera eficaz a los futuros especialistas en materia de patrimonio, fomentando y coordinando los trabajos de estudiantes y profesores de enseñanza superior en este ámbito.

El acta de creación de este Forum ha sido firmada por el Director General de la Organización, Federico Mayor, y por Justo Nieto, rector de la Universidad Politécnica de Valencia -que albergará el Forum- en presencia de la Ministra de Cultura, Carmen Alborch.

"Este Forum va a contribuir a la protección del patrimonio mundial, no sólo en su dimen- sión cultural, sino también desde una perspectiva sociológica y económica", declaró Federico Mayor. "Con esta firma, puede contar con mi apoyo personal", añadió, dirigiéndose al rector de la Universidad de Valencia.

El Forum desea principalmente implicar a los jóvenes en los grandes programas y campañas internacionales de la UNESCO para el patrimonio, promover encuentros entre profesores y estudiantes de todos los países, y reagrupar los equipos según proyectos interdisciplinares y concretos.

Más allá de su misión de formación y difusión del conocimiento, la enseñanza superior concentra hoy día gran parte de los investigadores, laboratorios e instalaciones relacionadas con la práctica cotidiana del trabajo relacionado con el patrimonio. Estas actividades son uno de los ejes principales de la UNESCO que, desde hace cincuenta años, se dedica a la protección del patrimonio cultural mundial.

Gracias a un banco de datos, y por medio de una gestión centralizada de recursos humanos y proyectos, el Forum deberá generar información sobre el patrimonio, censar las 